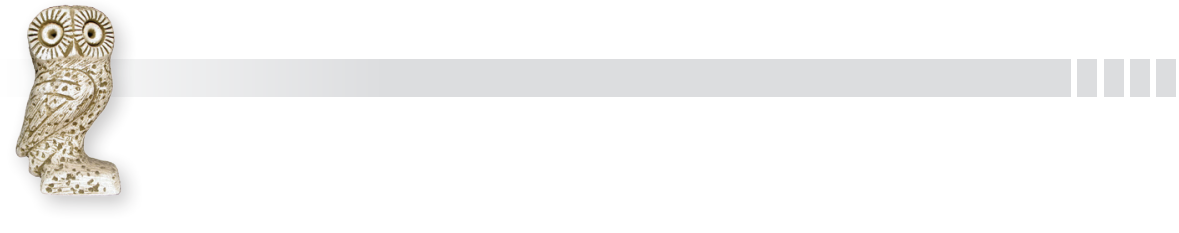

KEMIJA U NASTAVI

Uređuje: Nenad Raos

https://doi.org/10.15255/KUI.2019.055

KUI-20/2020

\title{
Puferi u nastavi. II. Priprema i upotreba
}

\author{
D. Dabić* i D. Petrin
}

Fakultet kemijskog inženjerstva i tehnologije, Sveučilište u Zagrebu

Marulićev trg 19, 10000 Zagreb

\begin{abstract}
Sažetak
U ovom tekstu razmatra se kako odabrati pufer ovisno o svrsi i kako ga pripraviti, pri čemu je navedeno nekoliko načina pripremanja puferskih otopina. Uz naglašeno nužno razumijevanje konstanti disocijacije kiselina, čitateljima se nastoji približiti ispravan način pripremanja željenih puferskih otopina. To se ponajprije odnosi na uzimanje u obzir svih faktora koji mogu utjecati na neki puferski sustav. $U$ tekstu se zato obrađuju važni pojmovi i povezuju s njihovim primjenama u znanstvenom i inženjerskom svijetu. Također, pojašnjava se pojam kapaciteta pufera i njegova uloga, pojam ionske jakosti te na što ona utječe. Navedena su bitna svojstva koja pufer treba imati te kako produljiti trajanje puferskih otopina. Na kraju se može provjeriti što su zapravo puferi te su dani zadatci s ciljem samostalne provjere usvojenosti rješavanja računskih zadataka.

Ključne riječi

Priprema pufera, kapacitet pufera, ionska jakost, koeficijenti aktiviteta, računski zadatci, nastava kemije
\end{abstract}

\section{Uvod}

Zanimljivo bi bilo zapitati se što su mislili Fernbach i Hubert ${ }^{1}$ 1900. dok su proučavali amilazu. Naime, primijetili su da se otopina čudno ponaša jer se opire promjeni vrijednosti $\mathrm{pH}$. No eto, 120 godina kasnije kada je potpuno jasno što je to bilo (fosfatni pufer je bio u igri), nastaje drugi problem da se poimanje pufera ponekad uzima zdravo za gotovo tijekom studija. A to dovodi do učenja navedenog gradiva bez razumijevanja (kako se to počesto naziva, učenja napamet ili "bubetanja"). Sukladno tome, studenti imaju poteškoća s rješavanjem računskih zadataka koji ipak zahtijevaju razumijevanje, što se može provjeriti kroz navedene zadatke na kraju ovoga rada. Posebno je to naglašeno kroz računske zadatke jer se pojedini zadatak može postaviti na različite načine. Drugim riječima, potrebno je primijeniti stečena znanja ne samo na ispitu nekog kolegija nego i nakon toga u životu. Da bi to bilo ostvarivo, prvo i osnovno je ovladati obrađenim pojmovima kroz prvi dio rada (Puferi u nastavi. I. Mjerenje vrijednosti $\mathrm{pH}$ i osnove teorije pufera), koji je objavljen u prošlom broju, kao i kroz ovaj tekst. To je osobito važno jer je to prvi i temeljni korak u rješavanju računskih zadataka. Naime, posebno uočljiv nedostatak osnova kemije prema našim iskustvima može biti u krivim odgovorima na sljedeća pitanja: a) ako je koncentracija natrijeva acetata $10 \mathrm{mM} \mathrm{u} 100 \mathrm{ml}$, kolika je množina i množinska koncentracija natrijeva acetata u $2 \mathrm{ml}$ te otopine;

*Autor za dopisivanje: dr. sc. Dario Dabić e-pošta:ddabic@fkit.hr b) ako se u $10 \mathrm{ml}$ otopine amonijeva formijata množinske koncentracije ( $c=0,40 \mathrm{M}$ ) doda $3 \mathrm{ml}$ vode, kolika je masena koncentracija amonijeva formijata u takvoj otopini? To se rezultira i na puferima, pa se ovo može nazvati nultom razinom koju je potrebno svladati. Jednostavno, ne bi se smjelo dovesti u pitanje da poveći broj studenata to ne zna na diplomskom studiju fakulteta nakon položenih kolegija iz više grana kemije. Dakle, cilj ovoga teksta je razjasniti osnovne pojmove, što bi u konačnici omogućilo potencijalno rješavanje većih problema u različitim područjima vezano uz pufere. To se odnosi na upotrebu pufera u industrijskoj proizvodnji higijenskih proizvoda (šampona ili sapuna), gdje je bitno $\mathrm{pH}$ takvih proizvoda održati približno jednakim vrijednostima $\mathrm{pH}$ ljudske kože $(\mathrm{pH}=5,5)$ kako ne bi došlo do iritacija. ${ }^{2}$ Također u analizi kvalitete riječnih i jezerskih voda primjenjuje se puferski kapacitet kao pokazatelj. ${ }^{3} \mathrm{U}$ biokemiji je pak važno usko $\mathrm{pH}$ područje za odvijanje određenih reakcija (npr. reakcije inhibicije enzima ili interakcija s enzimskim supstratima), pa se u te svrhe upotrebljavaju i pripremaju razni puferi (DTT, MOES, fosfatni, boratni, bikarbonatni). ${ }^{4} \mathrm{U}$ daljnjem tekstu je navedeno nekoliko načina pripremanja puferskih otopina što je pomalo zapostavljeno i premalo spominjano na nastavi kemije, a svakako je primjenjivo i osobito korisno znati.

\section{Odabir pufera}

Kako odabrati pufer ovisi o tome što se želi s puferom odnosno u koje ga se svrhe želi upotrebljavati. Ne vrijede ista načela ako pufer služi samo održavanju stalnih vrijednosti 
pH nekog sustava. Ili ako se pak pufer upotrebljava u biološkim sustavima kod enzima gdje, ovisno o vrsti pufera, može doći do inhibicije proteina. Dakle, nužno je odabrati pufer određene vrijednosti $\mathrm{pH}$ u skladu sa svrhom za koju se uporabljuje (npr. pokretnu fazu sustava HPLC-MS/MS) kao i voditi računa o koncentraciji i do koje mjere se pufer može miješati s vodom, a da pritom ne dođe do neželjenih reakcija (taloženja). Izrazito je važno znati je li takav pufer hlapljiv i prikladan za spektrometar masa kod elektroraspršenja kao izvora ionizacije. Treba imati to na umu jer takav problem zna biti prisutan u kromatografskim laboratorijima, a cijena takve pogreške iznosi barem nekoliko tisuća kuna. Osim toga, prisutni su i dodatni troškovi zbog privremene nemogućnosti rada na instrumentu.

Jedan od prvih koraka u pripravljanju pufera svakako je pronalazak kemikalija s poznatim vrijednostima $\mathrm{p} K_{\mathrm{a}}$ (tablica 1) na temelju kojih se pripravljaju puferi. Zatim slijedi odabir optimalnog pufera, o čemu će riječ biti kasnije u tekstu.
A što su zapravo konstante $K_{\mathrm{a}} i \mathrm{p} K_{\mathrm{a}}$ ? Konstanta disocijacije kiseline je ravnotežna konstanta čija brojčana vrijednost prikazuje omjer ravnotežnih koncentracija disociranog i nedisociranog oblika kiseline. Ona, u principu, govori koliki pH mora biti da bi neka tvar primila ili dala proton (vodikov ion). Budući da konstanta disocijacije kiseline/baze može varirati preko deset redova veličine, prikladnije ju je logaritmirati i iskazati kao potenciju s bazom 10 dodajući ispred slovo p. Isto kako se koncentracije oksonijevih iona iskazuju $\mathrm{pH}$ izrazom. Što je $\mathrm{p} K_{\mathrm{a}}\left(\mathrm{p} K_{\mathrm{b}}\right)$ vrijednost veća, to je kiselina (baza) slabija, tj. slabije disocira. Važno je zaključiti da za razliku od veličine $\mathrm{pK}_{\mathrm{a}}$, vrijednost $\mathrm{pH}$ ovisi o koncentraciji kiseline. Posljedično, koncentrirana octena kiselina koja pripada u slabe kiseline može imati niži pH od jake kiseline (npr. razrijeđene dušične kiseline). Osim toga, prema Brønsted-Lowryjevoj teoriji, kiseline su vrste koje mogu otpustiti hidron (proton), pa je tako očekivano $\mathrm{CH}_{3} \mathrm{COOH}$ kiselina. Međutim, je li neka tvar kiselina ili baza relativan je pojam, uvijek u odnosu na kiselost ota-

Tablica 1 - Prikaz vrijednosti $K_{\mathrm{a}}$ i $\mathrm{p} K_{\mathrm{a}}$ razrijeđenih vodenih otopina često korištenih slabih kiselina nulte ionske jakosti pri $25{ }^{\circ} \mathrm{C}$ (brojevi u zagradama predstavljaju stupanj disocijacije kiseline $)^{5}$

Table $1-K_{\mathrm{a}} \mathrm{i} \mathrm{p} K_{\mathrm{a}}$ constants for diluted aqueous solutions of some commonly used weak acids, at zero ionic strength and $25{ }^{\circ} \mathrm{C}$ (with degrees of dissociation given in parentheses) ${ }^{5}$

\begin{tabular}{|c|c|c|c|c|}
\hline $\begin{array}{l}\text { Kiselina } \\
\text { Acid }\end{array}$ & $\mathrm{HA}$ & $\mathrm{A}^{-}$ & $K_{\mathrm{a}}$ & $\mathrm{p} K_{\mathrm{a}}$ \\
\hline jodna (iodic) & $\mathrm{HIO}_{3}$ & $1 \mathrm{O}_{3}^{-}$ & $1,66 \cdot 10^{-1}$ & 0,78 \\
\hline oksalna (oxalic) (1) & $\mathrm{H}_{2} \mathrm{C}_{2} \mathrm{O}_{4}$ & $\mathrm{HC}_{2} \mathrm{O}_{4}^{-}$ & $5,62 \cdot 10^{-2}$ & 1,25 \\
\hline sumporna (sulphuric) (2) & $\mathrm{HSO}_{4}^{-}$ & $\mathrm{SO}_{4}{ }^{2-}$ & $1,02 \cdot 10^{-2}$ & 1,99 \\
\hline fosforna (phosphoric) (1) & $\mathrm{H}_{3} \mathrm{PO}_{4}$ & $\mathrm{H}_{2} \mathrm{PO}_{4}^{-}$ & $6,92 \cdot 10^{-3}$ & 2,16 \\
\hline kloroctena (chloroacetic) & $\mathrm{CH}_{2} \mathrm{ClCOOH}$ & $\mathrm{CH}_{2} \mathrm{ClCOO}^{-}$ & $1,35 \cdot 10^{-3}$ & 2,87 \\
\hline limunska (citric) (1) & $\mathrm{H}_{3} \mathrm{C}_{6} \mathrm{H}_{5} \mathrm{O}_{7}$ & $\mathrm{H}_{2} \mathrm{C}_{6} \mathrm{H}_{5} \mathrm{O}_{7}^{-}$ & $7,41 \cdot 10^{-4}$ & 3,13 \\
\hline fluorovodična (hydrofluoric) & HF & $\mathrm{F}^{-}$ & $6,31 \cdot 10^{-4}$ & 3,20 \\
\hline dušikasta (nitrous) & $\mathrm{HNO}_{2}$ & $\mathrm{NO}_{2}^{-}$ & $5,62 \cdot 10^{-4}$ & 3,25 \\
\hline mravlja (formic) & $\mathrm{HCOOH}$ & $\mathrm{HCOO}^{-}$ & $1,78 \cdot 10^{-4}$ & 3,75 \\
\hline oksalna (oxalic) (2) & $\mathrm{HC}_{2} \mathrm{O}_{4}^{-}$ & $\mathrm{C}_{2} \mathrm{O}_{4}{ }^{2-}$ & $1,55 \cdot 10^{-4}$ & 3,81 \\
\hline mliječna (lactic) & $\mathrm{HC}_{3} \mathrm{H}_{5} \mathrm{O}_{3}$ & $\mathrm{C}_{3} \mathrm{H}_{5} \mathrm{O}_{3}^{-}$ & $1,38 \cdot 10^{-4}$ & 3,86 \\
\hline benzojeva (benzoic) & $\mathrm{C}_{6} \mathrm{H}_{5} \mathrm{COOH}$ & $\mathrm{C}_{6} \mathrm{H}_{5} \mathrm{COO}^{-}$ & $6,31 \cdot 10^{-5}$ & 4,20 \\
\hline limunska (citric) (2) & $\mathrm{H}_{2} \mathrm{C}_{6} \mathrm{H}_{5} \mathrm{O}_{7}^{-}$ & $\mathrm{HC}_{6} \mathrm{H}_{5} \mathrm{O}_{7}^{2-}$ & $1,74 \cdot 10^{-5}$ & 4,76 \\
\hline octena (acetic) & $\mathrm{CH}_{3} \mathrm{COOH}$ & $\mathrm{CH}_{3} \mathrm{COO}^{-}$ & $1,74 \cdot 10^{-5}$ & 4,76 \\
\hline ugljična (carbonic) (1) & $\mathrm{H}_{2} \mathrm{CO}_{3}$ & $\mathrm{HCO}_{3}^{-}$ & $4,47 \cdot 10^{-7}$ & 6,35 \\
\hline limunska (citric) (3) & $\mathrm{HC}_{6} \mathrm{H}_{5} \mathrm{O}_{7}^{2-}$ & $\mathrm{C}_{6} \mathrm{H}_{5} \mathrm{O}_{7}{ }^{3-}$ & $3,98 \cdot 10^{-7}$ & 6,40 \\
\hline arsenska (arsenic) (2) & $\mathrm{H}_{2} \mathrm{AsO}_{4}^{-}$ & $\mathrm{HAsO}_{4}{ }^{2-}$ & $1,74 \cdot 10^{-7}$ & 6,76 \\
\hline fosforna (phosphoric) (2) & $\mathrm{H}_{2} \mathrm{PO}_{4}^{-}$ & $\mathrm{HPO}_{4}{ }^{2-}$ & $6,17 \cdot 10^{-8}$ & 7,21 \\
\hline hipoklorasta (hypochlorous) & $\mathrm{HClO}$ & $\mathrm{ClO}^{-}$ & $3,98 \cdot 10^{-8}$ & 7,40 \\
\hline hipobromasta (hypobromous) & $\mathrm{HBrO}$ & $\mathrm{BrO}^{-}$ & $2,82 \cdot 10^{-9}$ & 8,55 \\
\hline cijanovodična (hydrocyanic) & $\mathrm{HCN}$ & $\mathrm{CN}^{-}$ & $6,17 \cdot 10^{-10}$ & 9,21 \\
\hline amonijev ion (ammonium ion) & $\mathrm{NH}_{4}^{+}$ & $\mathrm{NH}_{3}$ & $5,62 \cdot 10^{-10}$ & 9,25 \\
\hline fenol (phenol) & $\mathrm{C}_{6} \mathrm{H}_{5} \mathrm{OH}$ & $\mathrm{C}_{6} \mathrm{H}_{5} \mathrm{O}^{-}$ & $1,02 \cdot 10^{-10}$ & 9,99 \\
\hline L-askorbinska (L-ascorbic) (2) & $\mathrm{HC}_{6} \mathrm{H}_{6} \mathrm{O}_{6}^{-}$ & $\mathrm{C}_{6} \mathrm{H}_{6} \mathrm{O}_{6}{ }^{2-}$ & $2,00 \cdot 10^{-12}$ & 11,70 \\
\hline fosforna (phosphoric) (3) & $\mathrm{HPO}_{4}{ }^{2-}$ & $\mathrm{PO}_{4}{ }^{3-}$ & $4,79 \cdot 10^{-13}$ & 12,32 \\
\hline
\end{tabular}


pala i drugih prisutnih tvari. Tako octena kiselina može i primiti proton od vrlo jake kiseline, tvoreći $\mathrm{CH}_{3} \mathrm{COOH}_{2}{ }^{+}$, pa je $\mathrm{CH}_{3} \mathrm{COOH}$ baza, a ne kiselina.

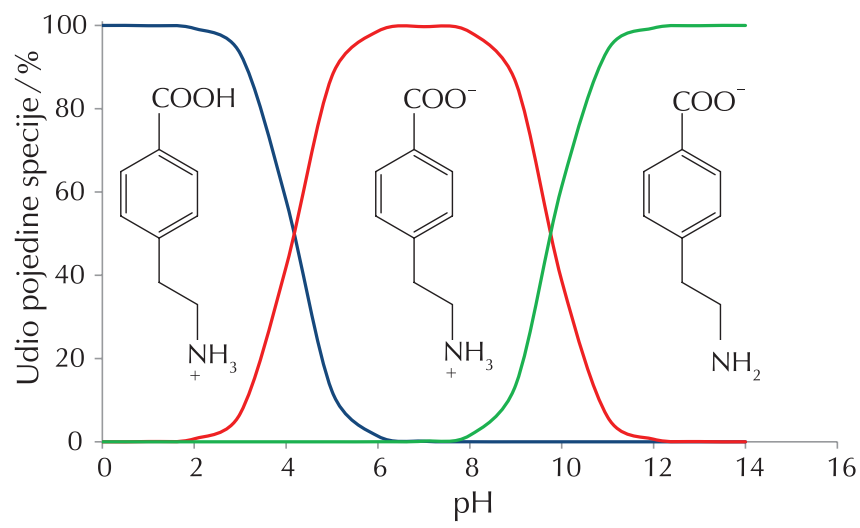

Slika 1 -Ovisnost udjela i raspodjele ionizacijskih specija molekule 4-(2-aminoetil)benzojeve kiseline o vrijednosti $\mathrm{pH}$

Fig. 1 -Dependence of mole fractions of ionic species for 4-(2-aminoethyl)benzoic acid and their distribution on $\mathrm{pH}$

$\mathrm{Na}$ primjeru 4-(2-aminoetil)benzojeve kiseline (slika 1) koja ima dvije $\mathrm{p} K_{\mathrm{a}}$-vrijednosti $\left(\mathrm{p} K_{\mathrm{a} 1}(-\mathrm{COOH})=4,14\right.$ te $\left.\mathrm{pK}_{\mathrm{a} 2}\left(-\mathrm{NH}_{2}\right)=9,80\right)$ može se vidjeti kako udio pojedine specije ovisi o vrijednosti $\mathrm{pH}$. Vrijednosti $\mathrm{p} K_{\mathrm{a}}$ izračunate su u programu Chemicalize. ${ }^{6}$ Kako onda odabrati pufer i kakve veze ima njegov $\mathrm{p} K_{\mathrm{a}} \mathrm{s}$ tim? Ovisno o $\mathrm{pH}$ željenog medija i drugim karakteristikama odabire se prikladni kiselo-bazni par, imajući u vidu da je pufersko djelovanje najučinkovitije u području gdje je $\mathrm{pH}$ jednak $\mathrm{p} K_{\mathrm{a}}$. Prema tome, treba odabrati takav kiselo-bazni par čija će vrijednost $\mathrm{p} K_{\mathrm{a}}$ biti što bliža željenom $\mathrm{pH}$. Tako je za pripremu puferirane otopine vrijednosti $\mathrm{pH}=4$ dobro upotrebljavati otopinu mliječne kiseline $\left(\mathrm{pK}_{\mathrm{a}}\left(\mathrm{HC}_{3} \mathrm{H}_{5} \mathrm{O}_{3}\right)=3,86\right)$ i njezine soli, natrijeva laktata. Ako se pak želi pripremati lužnati medij $\mathrm{pH}=9$, pogodna će biti otopina amonijaka i amonijeva klorida $\left(\mathrm{pK}_{\mathrm{a}}\left(\mathrm{NH}_{4}{ }^{+}\right)=9,25\right)$. Naravno, nema jedinstvenog pravila koliko se $\mathrm{pH}$ i $\mathrm{pK}_{\mathrm{a}}$ smiju razlikovati, osim što je poželjno da se ne prekorači baš vrijednost jedne pH-jedinice. U svakom slučaju, bitno je znati kakva se uloga očekuje od kapaciteta pufera, tj. kolika treba biti jakost pufera.

\section{Kapacitet pufera}

Kapacitet pufera definira se kao mjera sposobnosti pufera da se odupire promijeni vrijednosti $\mathrm{pH}$ nakon dodatka kiseline ili baze. Dakle, kapacitet pufera iznosi 1 kada se $1 \mathrm{~mol}$ neke kiseline ili baze doda 1 litri pufera i pri tome se $\mathrm{pH}$ promijeni za jednu jedinicu $\mathrm{pH}$.

$$
\beta=\mathrm{d} c_{\mathrm{b}} / \mathrm{d}(\mathrm{pH})=-\mathrm{d} c_{\mathrm{a}} / \mathrm{d}(\mathrm{pH})
$$

Izraz (1) uveo je D. D. Van Slyke dok je proučavao promjene

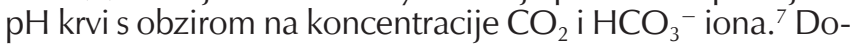
datkom kiseline promjena $\mathrm{pH}$ je po iznosu negativna $(\mathrm{pH}$ se smanjuje), a kako je vrijednost kapaciteta uvijek pozitivan broj, potrebno je u izraz staviti minus kada se radi o kiselini. Pisanje izvoda se preporučuje jer ako se samo za računanje kapaciteta pufera prikaže takav izraz (2); oznaka $C_{U}$ predstavlja koncentraciju pufera odnosno ukupnu koncentraciju kiseline u protoniranom i deprotoniranom obliku. ${ }^{8}$

$$
\beta=\ln 10 \cdot\left\{C_{\mathrm{U}} \cdot K_{\mathrm{a}} \cdot\left[\mathrm{H}^{+}\right] /\left(\left[\mathrm{H}^{+}\right]+K_{\mathrm{a}}\right)^{2}+K_{\mathrm{W}} /\left[\mathrm{H}^{+}\right]+\left[\mathrm{H}^{+}\right]\right\}
$$

To dovodi do naizgled teškog gradiva što svakako nije dobro ni za motivaciju studenata. Naime, kad je god moguće, kao možda u ovom slučaju, treba smanjiti opseg gradiva pa se može samo spomenuti koje sve prisutne tvari u otopini prilikom računanja kapaciteta pufera treba uzeti u obzir. Na nastavi matematike može se protumačiti, među ostalim, ${ }^{9}$ da kapacitet pufera predstavlja kontinuiranu i nelinearnu funkciju koja se može derivirati, što je prikazano matematičkim zapisom (1).

Bitnu ulogu puferski kapacitet ima kod riječnih voda gdje je usko pH-područje nužno za opstanak većine organizama. Ako je kapacitet prenizak te je pH vode izvan raspona kapaciteta, to može imati pogubne posljedice za čitav riječni ekosustav. Shodno tome, puferski kapacitet se često primjenjuje u analizi da bi se utvrdila kvaliteta vode. ${ }^{10}$ Inače, u slučaju smjese pufera može se primijeniti svojstvo aditivnosti pa je tako kapacitet pufera smjese slabe kiseline i baze mnogo veći nego kod spojeva međusobno vrlo sličnih pojedinačnih vrijednosti $\mathrm{p} K_{\mathrm{a}}$. Kapacitet pufera obično ovisi o koncentraciji upotrijebljenog pufera, pa je tako veći što je koncentracija pufera veća. ${ }^{8}$ Za pH to nije slučaj jer on ne ovisi o apsolutnoj koncentraciji pufera već o omjeru koncentracija njegovog (konjugiranog) kiselo-baznog para.

Na slici 2 može se vidjeti kako kapacitet pufera ovisi o pH otopine te kako je to povezano s udjelima specija u otopini. Budući da intenzivna i ekstenzivna svojstva vrijede i za pufere koji imaju oba svojstva, to je dobar način za prisjetiti se gradiva iz opće kemije s pitanjem koje bi to bilo intenzivno, a koje ekstenzivno svojstvo pufera. U slučaju primjene pufera skupa s organskim otapalima vrijedi uzeti u obzir da najčešće upotrijebljena organska otapala u kromatografiji (metanol i acetonitril) smanjuju kapacitet, ali i $p K_{\text {a }}$ pufera. ${ }^{11}$ Uz to, ako se i pripravlja npr. $20 \mathrm{mM}$ pufer u vodenoj otopini (kanal A), prilikom miješanja s 40 \% organskog otapala (iz kanala B) dolazi do razrjeđenja, što također smanjuje kapacitet pufera.

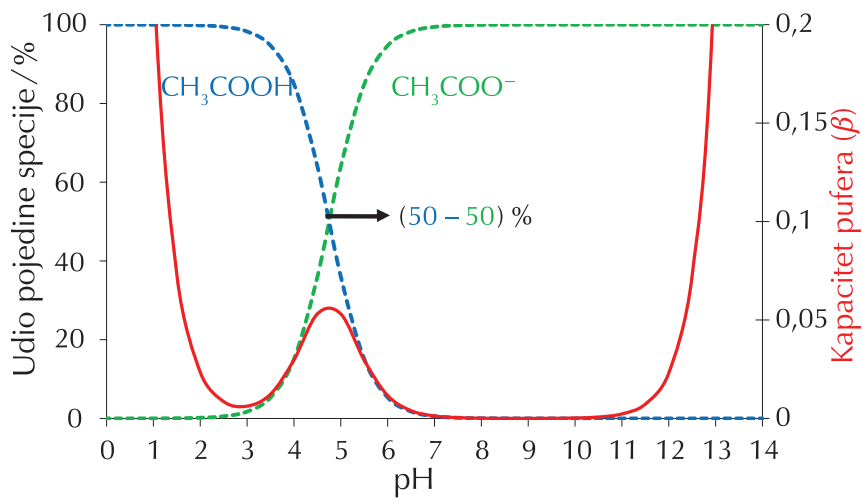

Slika 2 - Kapacitet acetatnog pufera koncentracije 0,1 M Fig. 2 - Buffer capacity of $0.1 \mathrm{M}$ acetic buffer 
Svaki puferski sustav ima područje djelovanja u kojem je najučinkovitiji, pa se općenito $\mathrm{pH}$ bira ovisno o vrijednosti $\mathrm{p} K_{\mathrm{a}}$ tako da ciljani $\mathrm{pH}$ bude \pm 1 od $\mathrm{p} K_{\mathrm{a}}$. Dakle, sve dok množina jedne tvari ne bude do 10 puta veća ili manja od druge, može se načelno govoriti o puferima. Prema tome, ako je vrijednost $\mathrm{p} K_{\mathrm{a}}=6,86$, onda je taj pufer djelotvoran u području pH od 5,86 do 7,86. Iznimka je karbonatni pufer koji je ipak učinkovit u održavanju pH krvi na 7,4 jer može održavati koncentracije hidrogenkarbonata i ugljikova dioksida u omjeru $20: 1 .{ }^{12}$ Aminokiseline također mogu biti puferi jer se ponašaju kao slabe kiseline ili baze pa tako mogu reagirati i kao kiseline i baze, npr. alanin i glicin djeluju kao puferi. Uobičajeni kapacitet pufera najčešće iznosi između 0,0001 i 0,01. Ipak da pH-raspon ne mora biti samo \pm 1 od $\mathrm{p} K_{\mathrm{a}}$-vrijednosti, pokazuje Britton-Robinsonov pufer. To je poznati univerzalni pufer koji djeluje u pH-području $2-12$, a sastoji se od smjese $0,04 \mathrm{M} \mathrm{H}_{3} \mathrm{BO}_{3 \prime}$ $0,04 \mathrm{M} \mathrm{H}_{3} \mathrm{PO}_{4}$ i 0,04 $\mathrm{M} \mathrm{CH}_{3} \mathrm{COOH}$, pri čemu se $\mathrm{pH}$ podešava s $0,2 \mathrm{M} \mathrm{NaOH}$ po potrebi. ${ }^{13}$

Sljedeći primjer može pokazati koliko je nužno da se unutar organizma vrijednost $\mathrm{pH}$ održava unutar uskih granica. Uobičajeno je za ljude da se pH krvi održava između 7,35 i 7,45 (vrijedi imati na umu da je pri $37^{\circ} \mathrm{C} \mathrm{pH}$ krvi neutralan na $\mathrm{pH}=6,80$, a ne na 7,00$)$. Mala promjena vrijednosti $\mathrm{pH}$ s 7,35 na 7,45 predstavlja promjenu koncentracije vodikovih iona u krvi za oko $20 \%$. Takvo stanje organizma kada vrijednost $\mathrm{pH}$ padne ispod 7,35 naziva se acidoza, a ako poraste iznad 7,45, alkaloza. Općenito vrijedi da promjena $\mathrm{pH}$ krvi u ljudskom organizmu za $\pm 0,2$ od normalne (srednje) vrijednosti, tj. izvan granica 7,2 i 7,6 redovito ima smrtne posljedice. ${ }^{12}$ Dakle, važnost pufera za postojanje ljudskog života je neprocjenjiva. Budući da se kod razdjelne kromatografije često primjenjuje puferirana pokretna vodena faza, korisno je znati da je kapacitet pufera od 0,01 do 0,1 uglavnom dovoljan za većinu kromatografskih određivanja u farmaceutskoj industriji. To znači da su koncentracije od 50 do 500 mM dovoljne, no u praksi se obično ide na niže koncentracije (približno od 5 do $20 \mathrm{mM}$ ), a kod MS-detektora i niže (iako je tada kapacitet pufera vrlo nizak).

\section{4. Žive li puferi dulje od muhe?}

Traju li puferi duže od životnog vijeka kućne muhe (15 - 30 dana), zasigurno je teško definirati jer ovisi o više čimbenika. No svakako je nužno poduzeti određene korake kako bi se produljilo vrijeme upotrebljivosti pufera. Dakle, potrebno je smanjiti i spriječiti stvaranje bakterija i gljivica, posebno u području $\mathrm{pH} 6-8$, pa se puferi čuvaju pri nižim temperaturama, upotrebljavaju se sterilni filtri (promjera pora od $0,22 \mathrm{~mm}$ ) ili se dodaje natrijev azid koncentracije $3 \mathrm{mmol} \mathrm{I}^{-1}(0,02 \%)$. Međutim, treba paziti da aditivi pufera budu u koncentraciji pri kojoj ne utječu negativno na sustav, posebno ako se radi o biološkim uzorcima. Primjerice, dodatak EDTA, DTT, $\mathrm{Mg}^{2+}$ u pufer može rezultirati promjenom vrijednosti $\mathrm{pH}$. Good i sur. ${ }^{14}$ dali su pregled značajnih svojstava koje pufer treba imati. To je topljivost, permeabilnost kroz biološke membrane, vrijednost $\mathrm{pK}_{\mathrm{a}}$ koja odgovara potrebnom rasponu i njihove promjene ovisne o temperaturi i o razrjeđenju. Određe- ni pufer karakterizira i interakcija s drugim tvarima (poput enzima, metalnih iona), područje UV-apsorpcije, netoksičnost i cijena. Naravno, i to da se neki puferi poput MOPS-a i HEPES-a raspadaju u autoklavu zbog povišene temperature.

\section{5. Što je ionska jakost i je li uopće važna?}

Još su Lewis i Randall 1921. opisujući koeficijente aktiviteta za jake elektrolite uveli pojam ionske jakosti. ${ }^{15}$ To je bilo i ostalo od velikog značaja jer je uočeno da prisutnost svih iona, kao i njihovi naboji znatno utječu na različita svojstva (konstantu disocijacije, topljivost soli).

Prema tome, ionska jakost otopine koja se temelji na množinskoj koncentraciji $\left(I_{\mathrm{c}}\right)$ jednaka je polovini zbroja produkata koncentracija (c) i kvadrata nabojnih brojeva $\left(z^{2}\right)$ svih iona prisutnih u promatranoj otopini (jedn. (3)). Drugim riječima, ioni u otopini stvaraju električno polje i upravo mjeru jačine toga polja iskazujemo (koncentracijskom ili molalitetnom) ionskom jakosti. Za otopine koje nisu aditivne po volumenu preporučuje se koristiti molalne ionske jakosti $\left(I_{\mathrm{b}} ; \mathrm{mol} \mathrm{kg}^{-1}\right)$.

Radi lakšeg uočavanja, korisno je naglasiti da je $I_{\mathrm{C}}$ za $\mathrm{KCl}$ četiri puta manji nego za otopinu $\mathrm{MgSO}_{4}$ zbog različitih nabojnih brojeva. Računski se može provjeriti i da će $I_{\mathrm{c}}$ za $\mathrm{AlCl}_{3}$ biti šest puta veća $u$ odnosu na $I_{\mathrm{c}}(\mathrm{KCl})$. No prava pitanja mogu pokazati i druge aspekte. Na primjer, studentima se može dati da izračunaju ionsku jakost za slabi elektrolit $\left(\mathrm{CH}_{3} \mathrm{COOH}\right)$ ili za teško topljivu sol $(\mathrm{CdS})$, što može biti "škakljivo" (engl. tricky) pitanje. Zato se tu mogu potaknuti studenti skloni programiranju kako bi došli na svoje.

$$
I_{c}=1 / 2 \sum c_{i} z_{i}^{2}
$$

Zašto nam je važna ionska jakost? Među ostalim jer ionska jakost ima utjecaj na koeficijente aktiviteta, kao i koeficijenti aktiviteta na nju. Prema Debye-Hückelovoj teoriji koeficijenti aktiviteta mogu se procijeniti pri određenim uvjetima. Da brojčana vrijednost koncentracije $\left(\mathrm{u} \mathrm{mol}^{-1}\right)$ bude jednaka aktivitetu, nužno je da koeficijent aktiviteta bude jednak 1 . On je za krutine 1 , ali za otopine to i nije tako. Slično kako se ponašanje idealnih plinova opisuje tako da molekule nemaju utjecaja jedna na drugu, tako i kod idealnih otopina možemo zanemariti doprinos međumolekulskih interakcija. Tada se navodi da su koeficijenti aktiviteta jednaki 1 .

Međutim, otopine nisu idealne. Pri većim koncentracijama $\left(\mathrm{mmol} \mathrm{I}^{-1}\right)$, čestice su bliže jedna drugoj, pa dolazi do odstupanja zbog privlačnih i odbojnih sila. Te sile ovise i o udaljenosti među česticama i o njihovom naboju, pa se takav utjecaj bolje opisuje ionskom jakosti. Ona, osim udaljenosti iona (koncentracije), u obzir uzima i jači utjecaj višestruko nabijenih iona (izraz (3)), pa se zato naboj uzima na kvadrat, kao i u elektrostatskim reakcijama. Utjecaj neidealnosti počinje biti značajan već pri koncentracijama od $1 \mathrm{mmoll}^{-1}$ jer se nabijene čestice osjećaju na dosta većim udaljenostima (sila pada s kvadratom udaljenosti), a van der Waalsove sile sa šestom potencijom. 
Nadalje, postavlja se pitanje što napraviti kada su koeficijenti aktiviteta manji od 1, a mijenjaju se ovisno o ionskoj jakosti?

Općenito je poznato da linearizacija nekakve funkcije olakšava račun jer se određeni oblik svodi na jednadžbu pravca. Međutim, koeficijenti aktiviteta se mijenjaju (posebno pri većim ionskim jakostima) i rezultat toga je da ovisnost $E$ o $\log C$ nije uvijek linearna. Što tada napraviti kada ne možemo pripremiti otopine istog aktiviteta? $U$ tom slučaju koeficijenti aktiviteta mogu se držati stalnima tako što se dodaje inertni elektrolit koji će povećati ionsku jakost. Mada ne treba zaboraviti da Nernstova jednadžba vrijedi samo za otopine niskih ionskih koncentracija $\left(<10^{-3} \mathrm{M}\right) .^{16}$ A ni to da se potenciometrom s pripadajućom elektrodom (indikatorskom i referentom elektrodom) mjeri uvijek aktivitet, a ne koncentracija iona (npr. $\mathrm{H}^{+}, \mathrm{Na}^{+}, \mathrm{Cl}^{-}$).

Nadalje, dodatkom neke soli u otopinu pufera nemoguće je izbjeći utjecaj ionske jakosti na konstantu disocijacije što pak utječe na odnos $\mathrm{pH}$ i $\mathrm{p} K_{\mathrm{a}}$ (kapacitet pufera). Ipak, nužno je znati kako pripremiti pufer uz podešavanje ionske jakosti. Ne treba zaboraviti da i puferi svojom disocijacijom doprinose ionskoj jakosti. Tada je najbolje uzeti to u obzir i dodati onoliko soli koliko je potrebno da bi se postigla željena ionska jakost (pritom je uračunat i doprinos ionske jakosti od strane pufera).

Naravno, pojednostavljenje i zanemarivanje različitih čimbenika utječe na rezultate. No, dok su odstupanja prihvatljiva, to je koristan način kako pripremiti pufer s određenom ionskom jakosti (posebno jer se uzima u obzir i ionska jakost samog pufera). Dakle, ionska jakost važan je čimbenik u mnogim područjima znanosti i industrije, osobito kod istraživanja enzimskih reakcija jer pri takvim uvjetima treba paziti na što je više moguće parametara. Osnovno je da treba raditi pri takvim ionskim jakostima koje odgovaraju fiziološkim uvjetima. To znači da koncentracija $\mathrm{NaCl}$ ili $\mathrm{KCl}$ treba biti između 100 i 200 mM. ${ }^{14}$ U suprotnom, ionska jakost može utjecati na katalitičku aktivnost enzima ako uvjeti nisu slični fiziološkim. Vrijedi imati na umu i činjenicu da fosfatni pufer tvori otprilike sedam puta više iona $\mathrm{u}$ mediju nego tris pufer pri istoj vrijednosti $\mathrm{pH}$. Također, ako se upotrebljava tris $\cdot \mathrm{HCl}$, a vrijednost $\mathrm{pH}$ se podešava s $\mathrm{NaOH}$, to uzrokuje nastanak natrijeva klorida. Posljedica toga je povećana koncentracija soli. To može kao posljedicu imati drugačije ponašanje proteina.

\section{Primjena stečenog znanja u laboratoriju}

Puferi u laboratoriju mogu se pripremiti na nekoliko naČina:

1) pripravom pufera iz slabe kiseline $i$ njezine konjugirane baze,

2) pripravom pufera iz slabe baze i njezine konjugirane kiseline,

3) pripravom pufera iz slabe kiseline i jake baze,

4) pripravom pufera iz slabe baze i jake kiseline.
Dakle, iz slabe kiseline i njezine konjugirane baze može se pripraviti acetatni pufer $\mathrm{pH}=4$, množinske koncentracije natrijeva acetata $c=0,2 \mathrm{M}$. Za izračun može se upotrijebiti $\mathrm{H}-\mathrm{H}$ jednadžba koja vrijedi za koncentracije kod kojih je $C_{\text {octene kiseline }}>100 \cdot K_{\mathrm{a}}$

$$
\mathrm{p} K_{\mathrm{a}}=\mathrm{pH}+\log ([\mathrm{NaOAc}] /[\mathrm{HAc}]) .
$$

Iz jedn. (4) može se odrediti da je uz natrijev acetat potrebno i 1,125 M octene kiseline. Međutim, ako se želi pripremiti pufer samo upotrebom octene kiseline, tada je potrebno uzeti više octene kiseline $(c=1,325 \mathrm{M})$ te zatim dodati $0,2 \mathrm{~mol} \mathrm{NaOH}$ (titrirati do ciljane vrijednosti $\mathrm{pH}$ ). Danas se mogu naći u priručnicima podatci koji navode volumen i koncentraciju jedne tvari, zatim volumen i koncentraciju druge tvari. Njihovim miješanjem $u$ zadanim omjerima može se isto pripraviti pufer (kao iz primjera broj 1). Međutim, prema našim iskustvima, to je dugotrajniji način za koji je potrebno i više posuđa, a često dovodi do pogreške. Umjesto toga, lako se odvaže određena tvar i otopi (u recimo $900 \mathrm{ml}$ vode), potom se samo titrira jakom lužinom/kiselinom do željene vrijednosti $\mathrm{pH}$ i na kraju nadopuni vodom do oznake u odmjernoj tikvici (od $1000 \mathrm{ml}$ ). Prilikom odvage određene tvari (primjerice kalijeva citrata dihidrata) veoma je važno uzeti u obzir i masu vode ako je prisutna, što znači da će se vagati veća masa kako bi se priredila željena koncentracija pufera. Isto kao što se kod odvage neke tvari, npr. farmaceutika koji se nalaze u obliku soli, odvaže veća masa (može se izračunati za koliko puta i pomoću gravimetrijskog faktora). To je jedna od pogrešaka koje su nažalost karakteristične za početnike i za veliku većinu studenata kemije. Osim što je vrlo važno znati stečeno znanje primijeniti u laboratoriju, važno je i to obaviti u razumnom vremenu. Tako se može postaviti pitanje kako pripraviti 1,00 I pufera vrijednosti $\mathrm{pH}=9,10$ koncentracije pufera 0,500 M upotrebljavajući samo $\mathrm{NH}_{4} \mathrm{Cl}(\mathrm{s})$, 1,00 $\mathrm{M} \mathrm{NH}_{3}$ i deioniziranu vodu. Poanta je riješiti zadatak u kratkom vremenu.

$$
\begin{gathered}
\mathrm{pH}=\mathrm{pK}_{\mathrm{a}}+\log \left(\left[\mathrm{NH}_{4} \mathrm{OH}\right] /\left[\mathrm{NH}_{4}{ }^{+}\right]\right) \\
m\left(\mathrm{NH}_{4} \mathrm{Cl}\right)=c\left(\mathrm{NH}_{4} \mathrm{Cl}\right) \cdot V(\text { otopine }) \cdot M\left(\mathrm{NH}_{4} \mathrm{Cl}\right) \\
V_{1}\left(\mathrm{NH}_{3}\right)=c_{2}\left(\mathrm{NH}_{3}\right) \cdot V_{2}\left(\mathrm{NH}_{3}\right) / C_{1}\left(\mathrm{NH}_{3}\right)
\end{gathered}
$$

Uvrštavanjem zadanih vrijednosti u jedn. (5) dobije se da ravnotežna koncentracija iznosi: $\left[\mathrm{NH}_{4}{ }^{+}\right]=0,690 \mathrm{M}$ te se preko jedn. (6) i (7) dođe do toga da odvagom $37 \mathrm{~g} \mathrm{NH}_{4} \mathrm{Cl}$ i dodatkom $500 \mathrm{ml}$ amonijaka koncentracije 1,00 $\mathrm{M}$ te nadopunjavanjem vode do oznake u odmjernoj tikvici od 1,00 I može se pripraviti pufer zadanih vrijednosti. Isto tako za pripravu $50 \mathrm{ml}$ puferirane otopine vrijednosti $\mathrm{pH}=7,00$ potrebno je odvagati $0,52 \mathrm{~g} \mathrm{NaHSO}_{3}$ i 0,39 g $\mathrm{Na}_{2} \mathrm{SO}_{3}$, s time da $\mathrm{pK}_{\mathrm{a}}\left(\mathrm{HSO}_{3}{ }^{-}\right)$iznosi 7,21 . U nastavku je dan primjer jednog zadatka za vježbu uz navedeno rješenje:

Zadatak 1. Izračunaj masu amonijeva klorida koji treba dodati u $250 \mathrm{ml}$ otopine amonijaka masenog udjela $w\left(\mathrm{NH}_{3}\right)=5,0 \%$, gustoće $\rho=0,98 \mathrm{~g} \mathrm{ml}^{-1}$ da bi se dobio pufer čiji je $\mathrm{pH}=9,8$ ako je $\mathrm{p} K_{\mathrm{b}}\left(\mathrm{NH}_{3}\right)=4,75$. Rješenje: $10,84 \mathrm{~g}$. 
Dakle, poanta je znati odabrati određenu kemikaliju i pripremiti pufer, npr. vrijednosti $\mathrm{pH}=9,00$ određenog volumena i koncentracije. Tako se, primjerice, na laboratorijskim vježbama može izvesti sasvim jednostavna vježba koja se, budući da je toliko jednostavna, gotovo nikad ne izvodi kao sama za sebe. Na vježbama se ne preporučuje dati studentima da upotrebljavaju "kuharicu" u kojoj piše koliko čega treba pomiješati, već se može postaviti pitanje kako bi pripremili pufer $(V=200 \mathrm{ml}, \mathrm{pH}=7,00 \mathrm{i}$ $c=0,01 \mathrm{M})$, a da imaju na raspolaganju sljedeće kemikalije: $\mathrm{NaH}_{2} \mathrm{PO}_{4}(\mathrm{~s}), \mathrm{Na}_{2} \mathrm{HPO}_{4}(\mathrm{~s}), \mathrm{Na}_{3} \mathrm{PO}_{4}(\mathrm{~s})$, propionsku kiselinu, natrijev propionat, $\mathrm{NaOH}(\mathrm{aq}) c(\mathrm{NaOH})=1,00 \mathrm{M}$, $\mathrm{HCl}(\mathrm{aq}) \mathrm{C}(\mathrm{HCl})=1,00 \mathrm{M}$ i destiliranu deioniziranu vodu uz sve potrebno laboratorijsko posuđe.

Za kraj je ostavljen brži pristup izračuna potrebne odvage odgovarajućih kemikalija za pripravu pufera. Dovoljno je potražiti buffer calculator i rezultat pretraživanja pokazat će nekoliko različitih kalkulatora za pripravu pufera kod kojih je moguće podešavati i ionsku jakost. Primjer jednog takvog kalkulatora može se pronaći i otvoriti u referenciji pod brojem 17.

U konačnici, kako bi znanje bilo praktično i primjenjivo, vrijedi ispitati razumije li student kako je elektromotivnost povezana s $\mathrm{pH}$ ? Kada mu se na vježbama objasni da uroni kombiniranu elektrodu, stisne "CAL" i potom je ispere. Nakon toga da uroni istu elektrodu u uzorak, stisne "READ" pa očita s ekrana vrijednost $\mathrm{pH}$. I to je to. Što je iz toga naučio, gotovo ništa. Međutim, što ako voditelj vježbi umjesto $\mathrm{pH}$ promijeni da se na ekranu prikazuju drugačije brojke (one za elektromotivnost). Tada nastane problem iz kojeg slijede pitanja što je to i što s tim. Daljnja mjerenja u pravilu se ne mogu provesti bez pomoći voditelja jer sve ostane na pokušaju kako sad iz toga preračunati na željenu vrijednost $\mathrm{pH}$. Međutim, upravo nakon vlastitog pokušaja studenata da riješe problem pa tek onda nakon objašnjenja voditelja vježbi uslijedi razumijevanje i postizanje željenog ishoda. Stoga, to je izvrstan način za provjeru stvarnog znanja.

\section{Kratka provjera znanja odabira pufera}

Pogledajmo jesu li sljedeći spojevi puferi ako se nalaze u vodenoj otopini u jednakim koncentracijama: 1) $\mathrm{NaOAc}$ i $\mathrm{KOAc}$, 2) $\mathrm{HF} \mathrm{i} \mathrm{F}-$, 3) $\mathrm{Na}_{2} \mathrm{SO}_{4}$ i $\mathrm{NaHSO}_{4}$, 4) $\mathrm{NH}_{4} \mathrm{OAc}$ i $\mathrm{NH}_{4} \mathrm{Cl}$, 5) $\mathrm{K}_{2} \mathrm{HPO}_{4}$ i $\mathrm{NaH}_{2} \mathrm{PO}_{4}$, 6) $\mathrm{KHSO}_{4}$ i $\mathrm{H}_{2} \mathrm{SO}_{4}$, 7) amonijak i salmijak, 8) $\mathrm{HCOOH}$ i HCOONa, 9) $\mathrm{HCl}$ i NaCl, 10) $\mathrm{C}_{2} \mathrm{H}_{5} \mathrm{NH}_{2}$ i $\mathrm{C}_{2} \mathrm{H}_{5} \mathrm{NH}_{3} \mathrm{NO}_{3}$, 11) $\mathrm{H}_{3} \mathrm{PO}_{4}$ i $\mathrm{NaH}_{2} \mathrm{PO}_{4}$, 12) $\left.\mathrm{NH}_{3} \mathrm{i}\left(\mathrm{NH}_{4}\right)_{3} \mathrm{PO}_{4}, 13\right) \mathrm{HN}_{3}$ i $\mathrm{NH}_{3}$, 14) monohidrat limunske kiseline $\left(\mathrm{C}_{6} \mathrm{H}_{8} \mathrm{O}_{7} \cdot \mathrm{H}_{2} \mathrm{O}\right)$ i trinatrijev citrat dihidrat $\left(\mathrm{C}_{6} \mathrm{H}_{5} \mathrm{O}_{7} \mathrm{Na}_{3} \cdot 2 \mathrm{H}_{2} \mathrm{O}\right)$, 15) piridin i piridinijev klorid, 16) $\mathrm{HClO}$ i NaClO, 17) otopina koja nastaje miješanjem $0,20 \mathrm{M} \mathrm{NH}_{3}$ i $0,10 \mathrm{M} \mathrm{HCl}, 18$ ) otopina koja nastaje miješanjem $0,20 \mathrm{M} \mathrm{NH}_{3}$ i $0,20 \mathrm{M} \mathrm{HCl}$. Odgovori idu redom: 1) ne, 2) da, 3) ne, 4) ne, 5) ne, 6) ne, 7) da, 8) da, 9) ne, 10) da, 11) da, 12) da, 13) ne, 14) da, 15) da, 16) da, 17) da, 18) ne.

Osim navedenih primjera, jeste li znali i da primjerice morska voda, ${ }^{3}$ Coca-Cola $^{18}$ i izbjeljivač ${ }^{19}$ djeluju kao puferi? Osim toga da konzervirani voćni sokovi imaju znatno veći kapacitet pufera nego gazirani sokovi i čajevi. ${ }^{20}$ Očigledno, navedeni primjeri sadrže tvari koje stvaraju pufere, od fosfata, citrata do hipoklorita. Nadalje, uvijek je važno gledati širi kontekst. Tako na primjer, vrijedi razmisliti, ako se želi pripremiti pufer vrijednosti $\mathrm{pH}=4,8$, je li bolje upotrijebiti acetatni ili citratni pufer ( $\mathrm{p} K_{\mathrm{a}}$ su navedene u tablici 1 ). Poanta je da oba pufera imaju slične $\mathrm{p} K_{\mathrm{a}}$ tako da će oba imati sličan kapacitet. No citratni je bolji jer ima još dvije konstante $\mathrm{p} K_{\mathrm{a}}$ koje su približno blizu (dok kod fosfata to nije slučaj), pa mogu i u tom području djelovati kao pufer. Ipak, ako se radi o pripravi pokretne faze pufera za analizu spektrometrom masa, onda svakako treba zaboraviti na citratni pufer zato što nije hlapljiv i taloži se, a i utječe na koroziju nehrđajućeg čelika. Za one koji promišljaju i izvan okvira vrijedi napomenuti da unatoč različitim prisutnim literaturama koje definiraju raspon $\mathrm{pH}$ (od 0 do 14), $\mathrm{pH}$ može biti i negativan, tj. izvan navedene skale, ${ }^{21}$ i da su zabilježeni takvi primjeri čak i u realnim vodama. ${ }^{22}$ Osim toga, zanimljivo je razmisliti koje su još prisutne poteškoće u eksperimentalnom mjerenju $\mathrm{pH}$ manjima od 1, osim što uobičajene $\mathrm{pH}$-elektrode nisu pogodne za takve uvjete. Problem je još i u puferskim otopinama. Efikasni puferi za tako niske $\mathrm{pH}$ nisu mogući jer da bi se postigla tako niska vrijednost $\mathrm{pH}$, kisela komponenta pufera trebala bi biti jaka kiselina s velikom konstantom disocijacije. A upravo ta velika konstanta disocijacije čini puferski kapacitet malim. Naravno, prisutni su i drugi utjecaji.

\section{Računski zadatci}

1) Kao pokretna faza u tekućinskoj kromatografiji visoke djelotvornosti, ali i u drugim tehnikama, vrlo često se upotrebljava otopina pufera kako bi, primjerice razvili optimalnu metodu za razdvajanje smjese 20 farmaceutika iz otpadnih voda. Tako uzmimo da je zadatak kromatografičara snimiti ukupno 71 uzorak. Metoda po uzorku traje $20 \mathrm{~min}$ uz protok $0,5 \mathrm{ml} \mathrm{min} \mathrm{m}^{-1}$. Za potrebe eksperimenta odabrana je $10 \mathrm{mM}$ koncentracija pufera. Koliko minimalno treba pripraviti pufera kako bi se analiza mogla pustiti preko noći (a da pumpa ne ostane bez otapala, eluensa) te kako pripraviti potrebne otopine pufera octene kiseline i natrijeva acetata vrijednosti $\mathrm{pH}=5,8$ ako $\mathrm{pK}_{\mathrm{a}}\left(\mathrm{CH}_{3} \mathrm{COOH}\right)$ je 4,8. Može li se kao otapalo za pripravu pufera umjesto vode upotrijebiti acetonitril? A može li se upotrijebiti metanol?

2) Ako se u čašu koja sadrži $0,044 \mathrm{~mol} \mathrm{NaH}_{2} \mathrm{PO}_{4} \mathrm{i}$ 0,061 mol $\mathrm{Na}_{2} \mathrm{HPO}_{4}$ u jednoj litri te otopine doda $1 \mathrm{ml} 40 \%$ otopine $\mathrm{NaOH}$, za koliko će se promijeniti $\mathrm{pH}$ tog pufera? $\mathrm{pK} \mathrm{a}_{\mathrm{a}}\left(\mathrm{NaH}_{2} \mathrm{PO}_{4}\right)=6,86$.

3) Koliki je pH pufera koji je dobiven miješanjem $20 \mathrm{ml}$ $0,035 \mathrm{M}$ mliječne kiseline $\left(\mathrm{C}_{3} \mathrm{H}_{5} \mathrm{O}_{3} \mathrm{H}\right)$ i $25 \mathrm{ml} \mathrm{0,040} \mathrm{M}$ laktatnog iona $\left(\mathrm{C}_{3} \mathrm{H}_{5} \mathrm{O}_{3}^{-}\right) .^{23}$

4) Izračunajte $\mathrm{pH}$ otopine amonijeve lužine koncentracije $0,025 \mathrm{~mol} \mathrm{dm}^{-3}$. Koliki će biti pH ako se u $250 \mathrm{ml}$ te otopine doda 1,40 g amonijeva klorida te za koliko će se promijeniti $\mathrm{pH}$ ako se u $250 \mathrm{ml}$ dobivene otopine koja sadrži $\mathrm{NH}_{4} \mathrm{OH}$ i NH $\mathrm{NH}_{4} \mathrm{Cl}$ doda $0,004 \mathrm{~mol} \mathrm{NaOH}$ ? $K_{\mathrm{a}}\left(\mathrm{NH}_{4} \mathrm{OH}\right)=1,8 \cdot 10^{-5}$.

5) Mravlja kiselina često se dodaje kao aditiv u pokretnu fazu spremnika HPLC instrumenta. Izračunajte koliki pH možete očekivati za 2 | 0,15 \% mravlje kiseline. 
6) U niskoj graduiranoj čaši otopljeno je u $50 \mathrm{ml}$ vode $0,550 \mathrm{~g}$ metilamina $\left(K_{\mathrm{b}}=4,4 \cdot 10^{-4}\right)$ te je potom ista otopina titrirana s $0,0116 \mathrm{gl}^{-1} \mathrm{HCl}$. Koliki je $\mathrm{pH}$ prije početka titracije, u točki ekvivalencije, a koliki nakon dodatka $50 \mathrm{ml}$ te $100 \mathrm{ml} \mathrm{HCl}$ ?

7) U odmjernoj tikvici od $100 \mathrm{ml}$ studentica Anđela dobila je u sklopu vježbi $25 \mathrm{ml}$ nepoznatog uzorka neke slabe monoprotonske kiseline množinske koncentracije 0,02 M. Navedeni uzorak je potom nadopunila do $100 \mathrm{ml}$ te je prije početka titracije $\mathrm{pH}$ te otopine iznosio 4,22. Koliko treba Anđela u $100 \mathrm{ml}$ otopine dodati $\mathrm{ml} 10 \mathrm{mM}$ otopine $\mathrm{NaOH}$ da pH otopine iznosi 5,22?

8) Esencijalna aminokiselina L-histidin hidrofilnog je karaktera i jedna je od triju aminokiselina s bazičnim ogrankom. Kao takva iznimno je važna u regulaciji i upotrebi esencijalnih elemenata poput željeza, bakra, molibdena, cinka i mangana. Također, histidin je važna aminokiselina za formiranje različitih veza i interakcija između metala, enzima i drugih tvari poput superoksid-dismutaze. ${ }^{24,25}$ Za potrebe istraživanja Menkesove bolesti koja se javlja zbog nedostatka bakra, potrebno je najprije izračunati koliko miligrama $\mathrm{KOH}$ treba dodati u $10 \mathrm{ml}$ otopine L-histidina hidroklorida $c=0,02 \mathrm{M}$ da se dobije potpuno deprotonirani oblik histidina, a koliko da se dobije pufer $\mathrm{pH}=9,0$, kako bi se pripremile navedene otopine. $\mathrm{p} K_{\mathrm{a} 1}=1,8$; $\mathrm{p} K_{\mathrm{a} 2}=9,2 ; \mathrm{p} K_{\mathrm{a}}$ (imidazolna skupina) $=6,0$.

9) Kolika je koncentracija dihidrogenfosfatnih iona $\left(p K_{a}=6,8\right)$ u otopini čiji pH iznosi 7,25 ako je ukupna koncentracija fosfatâ $0,20 \mathrm{M}$ ?

10) Koliki je pH otopine koja sadrži 0,6 mol mravlje kiseline i isto toliko natrijeva formijata? Koliko iznosi $\mathrm{pH}$ nakon dodatka 0,12 mol $\mathrm{HCl}$, a koliko nakon 0,12 mol $\mathrm{NaOH}$ u tu otopinu?

11) Ako 100 ml otopine sadrži 0,300 mol HF, koliko grama $\mathrm{NaF}$ treba dodati u tu otopinu da bi $\mathrm{pH}$ te otopine bio $\mathrm{pH}=3,00$ ako je $K_{\mathrm{a}}=7,2 \cdot 10^{-4}$.

12) U kojoj će od sljedećih kombinacija nastati pufer u čaši od 2 I vode kada se pomiješa:
a) $1 \mathrm{~mol} \mathrm{HNO}_{2}$ i $1 \mathrm{~mol} \mathrm{KNO}_{2}$
b) $1 \mathrm{~mol} \mathrm{HBr}$ i $2 \mathrm{~mol} \mathrm{KF}$
c) $1 \mathrm{~mol} \mathrm{HBr}$ i $1 \mathrm{~mol} \mathrm{KF}$
d) $1 \mathrm{~mol} \mathrm{HBr}$ i $2 \mathrm{~mol} \mathrm{KOH}$ ?

\section{9. Čemu sve to?}

Rješavanje problemskih zadataka individualnim i timskim radom izrazito je važan element u nastavi. Jednako kao što je razvijanje i stjecanje odgovornosti svakog pojedinca unutar grupe. Stoga, nije cilj obrazovanja samo znati reproducirati određena znanja. Isto tako, bolje je kada je u fokusu nastave učenik, a ne učitelj. Nažalost, takav pristup ex-cathedra još uvijek je poprilično zastupljen kako u srednjoškolskoj tako i na fakultetskoj razini. Još je tragičnije kada uz to nastavnik svodi nastavu na čitanje s PowerPoint prezentacije. Zato je u nastavku navedeno kako poticati radoznalost i timski rad na "dosadnim" dijelovima kemije, među koje se ubrajaju i puferi. To se može postići tako da jedna grupa treba "sagraditi" svoju pH-elektrodu (ili barem pronaći sve potrebne informacije kako bi to napravili) i objasniti čemu služi pojedini dio. Za to vrijeme druga dva tima trebaju prodati taj proizvod (koji smiju nadograditi), ali i argumentirati zašto kupiti baš njihov. Stoga, izrađivanje priručnika i poznavanje potrebnih pojedinosti oko izrade pH-metra u financijskim okvirima (što je također važno) samo je jedan mali, ali važan korak u obrazovanju. To je korak pripreme za realne situacije koje slijede nakon školovanja.

Treći tim koji se želi probiti na tržište ima zadatak osporiti prodaju pH-metara od drugog tima jer ne pružaju po njihovu mišljenju primjerenu metodologiju mjerenja pH složenih uzoraka (polučvrstih uzoraka hrane, bioloških, emuIzija itd.). Taj tim treba istražiti i nuditi prednosti primjene njihove elektrode, a profesor za to vrijeme može postavljati pitanja studentima. Tako, na primjer, koji bi pH teorijski dobili kada bi ga računali za $1 \cdot 10^{-8} \mathrm{M}$ otopinu $\mathrm{HCl}$. Poanta je da sami razmisle ima li taj rezultat smisla te što u takvom slučaju mogu napraviti? Što je to zapravo logaritam (mnogi to zaborave, ${ }^{26}$ u tom slučaju preporučujemo pogledati literaturu broj 26). Zatim, ako se $\mathrm{pH}$ promijeni s 4 na 2 , koliko puta se povećala koncentracija oksonijevih iona? Kako to da je pH destilirane vode rijetko kada 7,0, već je nešto niži? Koja su ograničenja Henderson-Hasselbachove jednadžbe? Je li je i zašto potrebno umjeravanje pH-članka prije potenciometrijske titracije? Svakako, mogu biti postavljena i zahtjevnija pitanja, npr. je li prilikom mjerenja $\mathrm{pH}$ potrebno miješati otopinu? Utječe li na $\mathrm{pH}$ ako otopina $0,01 \%$ mravlje kiseline sadrži 20 \% acetonitrila? Što ako otopina nije miješana za vrijeme mjerenja pH uzoraka, ali je zato miješana za vrijeme umjeravanja pH-članka na magnetskoj miješalici? Kako prisutnost sulfida u otopini kod mjerenja pH može utjecati na referentnu elektrodu? Je li topljivost $\mathrm{AgCl}$ u otopini $\mathrm{KCl}$ veća nego u vodi? Kako bi dodatak $\mathrm{Ag}^{+}$ u KCl utjecao na takvu referentnu elektrodu? Ne očekuje se od studenata da nužno daju točne odgovore, nego da raspravljaju i kritički razmišljaju, sve kako bi jednoga dana znali pristupiti rješavanju novih problema, unatoč tome što možda u prvi tren pomisle da ne znaju odgovor.

\section{Zaključak}

U članku su razmatrani temeljni pojmovi poput konstante disocijacije i kapaciteta pufera s obzirom na to da se navedeni pojmovi znatno primjenjuju u kemiji (u tekućinskoj kromatografiji), kemiji okoliša (otpadnim vodama), biomedicinskom području (radu s enzimima) i sl. Kroz tekst se nastojalo dati jasnija tumačenja nedostatno razumljivih pojmova vezanih uz pufere. Pokušalo ih se primijeniti na većem broju primjera iz prakse želeći pomoći onima koji tu nailaze na poteškoće. Zato se u tekstu nalaze i riješeni primjeri zadataka, a na kraju su dodani računski zadatci kako bi čitatelji mogli sami provjeriti i proširiti svoje znanje. Posebno jer studenti često znaju reći da im nedostaje zadataka iz kojih bi vježbali jer eto takvih koji budu na ispitu nema nigdje. Stoga treba poticati studente da se služe raznovrsnom literaturom poput časopisa Journal of Chem- 
ical Education te časopisa na hrvatskom jeziku Kemija u industriji. To znači da im se mogu preporučiti članci Kemije u nastavi.

Nadalje, kako bi obrađeni pojmovi bili više naglašeni, poželjno je tijekom studija upotrebljavati različite programske pakete s ciljem olakšavanja shvaćanja gradiva koje se uči. Naime, na Sveučilištu u Zagrebu u sklopu odsjeka Kemije na PMF-u izvode se vježbe molekulskog modeliranja, dok se na FKIT-u studenti u manjoj mjeri susreću s programima za razvoj metoda, optimiranje i vođenje kromatografskih analiza. Pozitivno je što se MATLAB često upotrebljava kao i Mathematica. Međutim, isto tako može se upotrebljavati i program Chemicalize (kao i drugi slični programi), ali za proučavanje ovisnosti topljivosti i $\log P$ o udjelu pojedinih tvari, kao i za procjenu vrijednosti $\mathrm{p} K_{\mathrm{a}}$ onih spojeva za koje ne postoje eksperimentalno određeni podatci. Stoga se na nastavi jasnije može vidjeti kako se vrijednosti $\mathrm{pK} K_{\mathrm{a}}$ mijenjaju ovisno o pripadajućem $\mathrm{pH}$. Budući da su potrebne značajne promjene u nastavi kemije vezano uz unaprjeđenje prethodno navedenih pojmova, jedan od načina kako to napraviti može biti primjenom navedenih alata.

Osim toga, umjesto klasičnih seminarskih radova o cijeloj jednoj analitičkoj metodi, mogu se dati i zadatci koji se tiču svih koji rade u laboratoriju, a to je priprema eksperimenata. To znači da studenti trebaju sami pripraviti pufere za umjeravanje pH-članka, teorijski potkrijepiti kako bi izmjerili $\mathrm{pH}$ morske vode, vodovodne i deionizirane vode te opisati što očekuju od dobivenih rezultata. Nakon toga, mogu se poprilično brzo i napraviti navedeni eksperimenti kako bi studenti sami pratili i naveli opaženo. Pri tome, treba omogućiti uspoređivanje rezultata pa jedna grupa neka upotrijebi kupovne otopine pufera za umjeravanje pH-članka, druga one koje su sami pripravili, a treća da prati kako bi temperatura mogla utjecati kod navedenih eksperimenata. Zaključno, potrebno je unaprjeđivati praktična znanja, ali novijim pristupom, onako kako je prof. Sikirica naveo: "znanje teče od onih koji nešto znaju prema onima koji to još ne znaju, a ne nužno od starijih prema mlađima". ${ }^{27}$ Stoga, važno je "razbijati" barijeru između profesora i studenata tako da se potiče studente da postavljaju pitanja i kritički razmišljaju.

\section{Popis kratica \\ List of abbreviations}

EDTA - etilendiamintetraoctena kiselina - ethylenediaminetetraacetic acid

DTT - ditiotretol - dithiothreitol

MOPS - 3-(N-morfolino)propansulfonska kiselina - 3-(N-morpholino)propanesulfonic acid

HEPES - 4-(2-hidroksietil)-1-piperazinetanosulfonska kiselina - 4-(2-hydroxyethyl)-1-piperazineethanesulfonic acid

Tris - tris(hidroksimetil)aminometan - tris(hydroxymethyl)aminomethane

\section{Literatura}

\section{References}

1. D. D. Perrin, B. Dempsey, Buffers for $\mathrm{pH}$ and metal ion control, Springer, Dordrecht, 1974., str. 1-3.

2. J. Tarun, J. Susan, J. Suria, V. J. Susan, S. Criton, Evaluation of $\mathrm{pH}$ of bathing soaps and shampoos for skin and hair care, Indian J. Dermatol. 59 (2014) 442-444, doi: https://doi. org/10.4103/0019-5154.139861.

3. W. Guo, Seawater temperature and buffering capacity modulate coral calcifying pH, Sci. Rep. 9 (2019) 1-13, doi: https://doi.org/10.1038/s41598-018-36817-y.

4. C. Martin, B. Michalet-Doreau, Variations in mass and enzyme activity of rumen microorganisms: Effect of barley and buffer supplements, J. Sci. Food Agric. 67 (1995) 407-413, doi: https://doi.org/10.1002/jsfa.2740670319.

5. D. R. Lide, CRC Handbook of chemistry and physics, $84^{\text {th }}$ edition, CRC Press 2003.-2004., str. 1240-1252.

6. URL: https://chemicalize.com/ (19. 12. 2019.).

7. E. T. Urbansky, M. R. Schock, Understanding, deriving and computing buffer capacity, J. Chem. Educ. 77 (2002) 16401644.

8. Nj. Radić, L. K. Modun, Uvod u analitičku kemiju, Školska knjiga, Zagreb, 2016., str. 130-133.

9. A. G. Asuero, Buffer capacity of a polyprotic acid: First derivative of the buffer capacity and $\mathrm{p} K_{\mathrm{a}}$ values of single and overlapping equilibria, Crit. Rev. Anal. Chem. 37 (2007) 269301, doi: https://doi.org/0.1080/10408340701266238.

10. URL: https://research.cbc.osu.edu/reel/research-modules/ environmental-chemistry/methods/buffer-capacity/ (20. 7. 2019.).

11. X. Subirats, M. Rosés, E. Bosch, On the effect of organic solvent composition on the $\mathrm{pH}$ of buffered HPLC mobile phases and the $\mathrm{pK}_{\mathrm{a}}$ of analytes-A review, Sep. Purif. Rev. 36 (2007) 231255, doi: https://doi.org/10.1080/15422110701539129.

12. J. Lovrić, pH i puferi, Medicinar 45 (2004) 20-23.

13. H. T. K. Britton, R. A. Robinson, Universal buffer solutions and the dissociation constant of veronal, J. Chem. Soc. 0 (1931) 1456-1462, doi: https://doi.org/10.1039/JR9310001456.

14. N. E. Good, G. D. Winget, W. Winter, T. N. Connoly, S. Izawa, R. M. M. Singh, Hydrogen ion buffers for biological research, Biochemistry 5 (1966) 467-477, doi: https://doi. org/10.1021/bi00866a011.

15. G. N. Lewis, M. Randall, The activity coefficient of strong electrolytes, J. Am. Chem. Soc. 43 (1921) 1112-1154, https://doi.org/10.1021/ja01438a014.

16. URL: https://chem.libretexts.org/Bookshelves/General_Chemistry/Book\%3A_Chem1_(Lower)/16\%3A_Electrochemistry/24.04\%3A_The_Nernst_Equation (27. 10. 2019.)

17. URL: https://www.liverpool.ac.uk/pfg/Research/Tools/ BuffferCalc/Buffer.html (21.10. 2019.)

18. S. H. de Carvalho Sales-Peres, A. C. Magalhães, M. A. de Andrade Moreira Machado, M. A. Buzalaf, Evaluation of the erosive potential of soft drinks, Eur. J. Dent. 1 (2007) 10-13.

19. L. P. Lynch, C. R. Nodder, Some observations on the $\mathrm{pH}$ values of hypochlorite solutions, J. Text. Inst. 23 (1932) 309 318, doi: https://doi.org/10.1080/19447023208661562.

20. S. Singh, R. Jindal, Evaluating the buffering capacity of various soft drinks, fruit juices and tea, Conserv. Dent. 13 (2010) 129-131, doi: https://doi.org/10.4103/0972-0707.71643.

21. K. F. Lim, Negative pH does exist, J. Chem. Educ. 83 (2006) 1465, doi: https://doi.org/10.1021/ed083p1465. 
22. D. K. Nordstrom, C. N. Alpers, C. J. Ptacek, D. W. Blowes, Negative $\mathrm{pH}$ and extremely acidic mine waters from iron mountain, California, Environ. Sci. Technol. 34 (2000) 254258, doi: https://doi.org/10.1021/es990646v.

23. M. Orgill, A. Sutherland, Undergraduate chemistry students' perceptions of and misconceptions about buffers and buffer problems, Chem. Educ. Res. Pract. 9 (2008) 131-143, doi: https://doi.org/10.1039/B806229N.
24. L. Stryer, W. H. Freeman, Biochemistry, $3^{\text {rd }}$ Ed., New York, 1988., str. 19-588.

25. URL: https://aminoacidsguide.com/His.html (2. 11. 2019.).

26. F. M. Brückler, Logaritmi - matematika u kemiji ili kemija u matematici?, Pula, 2013., str. 11-14.

27. M. Sikirica, Kako načiniti kristale limunske kiseline i šećera, Kem. Ind. 68 (2019) 609-614, doi: https://doi.org/10.15255/ KUI.2019.025.

\section{SUMMARY \\ Buffers in Education. II. Preparation and Use \\ Dario Dabić* and Damjan Petrin}

The text discusses how to choose buffers depending on the purpose, and how to prepare them in several ways. With the necessary understanding of acid dissociation constants and buffer mechanisms, it is meant to give the readers the correct approach when preparing desired buffer solutions by taking into account all factors that may affect the buffer system. Therefore, the text covers important concepts, and links them with their applications in the world of science and engineering. It also explains buffer capacity and its role, as well as the concept of ionic strength and how it affects the $\mathrm{pH}$. At the end, explanations of buffers are summarized and some numerical problems are given to enable self-evaluation of the comprehension of the given subject.

\section{Keywords}

Preparation of buffers, buffer capacity, ionic strength, coefficient of activity, numerical problems, chemical education

Faculty of Chemical Engineering and

Technology, University of Zagreb

Marulićev trg 19

10000 Zagreb, Croatia
Professional paper Received October 29, 2019 Accepted January 21, 2020 